At-Tarbawi: Jurnal Pendidikan, Sosial dan Kebudayaan

Volume 7 Nomor 2 Tahun 2020

doi: 10.32505/tarbawi.v8i2.2036

\title{
Reaktualisasi Pendidikan Aqil Baligh di Sekolah
}

\author{
Wahidah \\ IAIN Langsa \\ wahidah@iainlangsa.ac.id
}

\begin{abstract}
The article discusses how aqil baligh education in schools can be implanted by teachers so that between baligh and aqil parallels hand in hand, there is no gap between the two. Data collection using review literature methods analyzes various information from various writing sources of both books, modules, journal articles and other research results. To implement aqil baligh education in schools can be done by taking three steps. The first step is to make the educational targets that of designing the proper curriculum in order. Which functions are that it parallels biological maturity, psychological and social maturity as well as financial. Second, implementing a project-based learning process that is, a learning model that develops an understanding of concepts through meaningful problem investigation and can produce a real product or real experience such as an internship. Third, learning by creating learning communities through the learning cooperative learning model. The method of cooperative learning is shown to improve learner learning independence.
\end{abstract}

Keyword: Aqil, Baligh, Learning Model, Reactualization

\begin{abstract}
Abstrak
Artikel mendiskusikan bagaimana pendidikan akil baligh di sekolah dapat ditanamkan oleh para guru sehingga antara baligh dan aqil sejajar beriringan, tidak terjadi kesenjangan antara keduanya. Pengumpulan data dengan menggunakan metode literatur review mengalisis berbagai informasi dari berbagai sumber tulisan baik buku, modul, artikel jurnal dan hasil penelitian lainnya. Untuk menerapkan pendidikan aqil baligh di sekolah dapat dilakukan dengan menempuh tiga langkah. Langkah pertama adalah membuat target pendidikan dengan jelas yaitu mendesain kurikulum yang tepat guna. Yang fungsinya yaitu mensejajarkan kedewasaan bilogis, kedewasaan psikologis dan sosial serta finasial. Kedua, menerapkan proses pembelajaran yang berbasis proyek yaitu model pembelajaran yang mengembangkan pemahaman konsep melalui investigasi masalah yang bermakna dan dapat menghasilkan suatu produk nyata atau pengalaman yang real seperti magang. Ketiga, pembelajaran dengan menciptakan komunitas belajar melalui model pembelajaran cooperative learning. Metode pembelajaran kooperatif learning terbukti dapat meningkatkan kemandirian belajar peserta didik.
\end{abstract}

Kata Kunci: Aqil, Baliqh, Model Pembelajaran, Reaktualisasi 


\section{A. Pendahuluan}

Masa remaja merupakan suatu stadium dalam siklus perkembangan anak. Rentang usia remaja antara usia 12 sampai 21 tahun bagi wanita, dan 13 sampai 22 tahun bagi pria. Masa remaja dibagi menjadi masa remaja awal dan masa remaja akhir. Periode sebelum masa remaja disebut sebagai ambang pintu masa remaja atau periode pubertas. Istilah remaja ini telah mempengaruhi masayarakat bahkan dunia pendidikan untuk menganggap bahwa mereka wajar dalam melakukan berbagai hal yang menyalahi baik dari segi norma agama maupun norma hukum.

Mukhlas (2008) menjelaskan seringkali remaja tidak diberikan kesadaran akan tanggung jawab sebagai seorang remaja. Mereka masih dianggap anak-anak. Padahal sebagai generasi muda, usia remaja memerlukan bimbingan dan arahan dari pihak-pihak yang bertanggung jawab, guna memberi rasa aman dan diharapkan dapat berkembang dengan baik. Sebenarnya ada keresahan di tengah masyarakat terhadap perilaku menyimpang remaja ini seperti pelecehan seksual.

Kasus pelecehan seksual yang melibatkan anak-anak pada beberapa kota besar di Indonesia terus meningkat. Sebagaimana disebutkan bahwa di wilayah Surabaya kasus pelecehan seksual mengalami kecenderungan peningkatan dari tahun ke tahun sejak 2012-2016 (Bella dan Istianah 2017). Khususnya baik sebagai korban maupun pelaku, tidak sedikit yang melibatkan anak-anak usia sekolah dasar. Oleh sebab itu, masalah ini penjadi sangat penting untuk diperhatikan, karena sungguh disayangkan apabila generasi yang masih diusia belia sudah dirusak mental, moral, bahkan fisiknya oleh tindakan seksual yang menyimpang. Selain itu ada penyimpangan prilaku remaja lainnya yang sering terjadi.

Dari berbagai media nasional bahwa pada masa sekarang ini, banyak dihadapkan persoalan yang dihadapi oleh masyarakat, terutama di kota besar dan bahkan sudah nampak sampai di pedesaan, yaitu mulai maraknya tindak kriminalitas yang dilakukan oleh kalangan remaja. Kenakalan remaja sudah mulai meningkat dan bergeser, bukan hanya sekedar kenakalan biasa-biasa 
saja (normal) atau hanya sekedar iseng-iseng, akan tetapi kenakalan remaja saat ini sudah pada tindakan kriminalitas (Unayah dan Sabarisman 2015).

Salah satu faktor kriminalitas dikalangan remaja karena tidak adanya reaksi yang jelas (celaan, teguran atau sanksi kemasyarakatan lain), secara konsisten dan berkelanjutan dari masyarakat, cenderung menjadi-kan semakin kuatnya pemaknaan remaja terhadap perilaku-perilaku mereka dan pada gilirannya berkembang menjadi kebiasaan (Hadisuprapto 2004). Hal ini diperkuat oleh penelitian Susanti (2015) bahwa perilaku menyimpang remaja juga didukung karena adanya kontrol sosial yang lemah di masyarakat. Susanti menemukan bahwa masyarakat Desa Karangmojo cenderung membiarkan perilaku menyimpang terjadi dengan tanpa adanya sanksi yang membuat jera pelakunya. Penelitian ini menemukan bahwa masyarakat hanya memberikan sanksi atas prilaku menyimpang dari remaja yang menjadi pelaku seks bebas, prostitusi, pelaku miras dan narkoba adalah cibiran dari mulut ke mulut tanpa adanya teguran atau pengucilan serta arahan.

Rochaniningsih (2014) mengungkapkan bahwa kenakalan remaja merupakan gejolak kehidupan yang disebabkan adanya perubahan sosial di masyarakat. Perubahan tersebut misalnya pergeseran fungsi dan peran keluarga pada masyarakat modern. Peran dan fungsi keluarga sebagai lembaga sosialisasi dan afeksi telah mengalami perubahan yang menyebabkan terganggunya proses sosialisasi anak dalam keluarga. Konsekwensinya, saat ini banyak anak remaja yang berperilaku menyimpang seperti pergaulan bebas (sex bebas) di kalangan remaja. Dalam menyikapi fenomena kriminalitas yang dilakukan remaja pada saat ini, yang semakin nekat, berani tanpa rasa takut dan terus meningkat, harus dilihat sisi psikologis individual pelaku, pola asuh keluarga, komunitas dan masyarakat secara luas. Untuk menekan pergaulan bebas dikalangan remaja Rochaniningsih melihat tidak cukup hanya berupa penanaman nilai keagamaan yang kuat. Akan tetapi dibutuhkan pendampingan orang tua dalam segala hal, dengan tidak mengurangi kebebasan dari seorang anak. 
Fungsi sosialisasi dan afeksi dalam keluarga perlu ditumbuhkan kembali, mengingat keluarga adalah salah satu lembaga sosial yang paling dasar yang berperan membentuk karakter anak. Penelitian ini tidak menyinggung tentang peran sekolah dalam membentuk kepribadian remaja yang sudah masuk masa aqil baligh.

Diskursus kenakalan remaja juga dibahas oleh Sumara, dkk (2017) yang mengalisis faktor kenakalan remaja baik secara internal berupa krisis identitas atau karena remaja gagal mencapai masa integrasi kedua dimana pada diri remaja ada perubahan biologis dan sosiologis pada diri remaja memungkinkan terjadinya dua bentuk integrasi. Pertama, terbentuknya perasaan akan konsistensi dalam kehidupannya. Kedua, tercapainya identitas peran, tatkala identitas peran ini gagal maka kontrol diri seorang remaja melemah. Penyebanya dari gagalnya memahami dan membedakan tingkah laku yang dapat diterima dengan yang tidak dapat diterima ujungnya mereka terseret pada perilaku 'nakal'.

Pemahaman keagaaman yang rendah serta kurangnya perhatian dari orang tua, serta kurangnya kasih sayang juga merupakan faktor berikutnya. Sumara juga menyinggung adanya proses pendidikan yang kurang efektif seperti anak tidak berada di sekolah baik karena ada jam pelajaran yang kosong. Selain itu, penyebab penyimpangan perilaku juga dapat disebabkan oleh faktor internalnya yaitu: kontrol diri yang lemah, kurangnya motivasi untuk merubah perilaku, dan lemahnya kesadaran beragama. Sedangkan faktor eksternalnya yaitu: kurangnya motivasi dari orang tua, kurangnya perhatian dari orang tua, permasalahan dalam keluarga dan perceraian orang tua, kesalahan pola asuh orang tua, dan pengaruh teman sebaya atau lingkungan pergaulan (Putri 2018).

Dari berbagai kajian di atas terlihat ada hal mendasar yang terabaikan terkait istilah remaja. Penggunaan istilah ini berimplikasi pada persoalan psikologi yang berkaitan dengan kepribadian remaja yang mantap, serasi dan dewasa. Sehingga proses pendidikan terlihat memposisikan remaja pada kategori anak-anak meskipun secara fisik sudah baligh yang bisa saja terjadi sejak usia sekolah dasar atau kira kira sejak sekitar kelas 5 SD, yaitu sejak usia 
10 tahun. Yaitu ditandai dengan datangnya menstruasi bagi perempuan dan mimpi basah bagi anak laki-laki. Pada fase ini peserta didik seharusnya sudah ditanamkan kesadaran sebagai manusia yang memiliki peran dan tanggung jawab dan jika tidak menjalankan tanggung jawab dapat diberikan hukuman yang sifatnya mendidik. Misalkan sudah boleh dipukul (asal tidak melukai atau menghinakan) jika tidak melaksanakan perintah sholat. Pada masa ini juga disebut prabalighh dimana anak perlu diarahkan dan diberikan pendidikan baik keimanan, akhlak, fisik, intelektual dan skill, agar kelak setelah usia balighh menjadi anak yang mandiri dan dapat berkarya untuk diri sendiri, keluarga dan masyarakat (Sholichah 2020).

Konsekwensi logis dari pengabaian atas diri anak yang sudah baligh akan kesadaran pada peran dan tanggung jawab adalah banyak remaja yang belum dapat menjalankan kewajibannya dengan benar. Karena hal demikian terjadi pembiaran karena dianggap masih masa remaja yaitu masa peralihan dari kanak-kanak menjadi dewasa dalam segala segi. Karena dianggap masih remaja, seorang anak dianggap wajar jika mengalami kegoncangan dan ketidakpastian sehingga melahirkan prilaku over yang sering disebut kenakalan remaja. Kenakalan remaja dan tindakan negatif lainnya terjadi karena tidak adanya rasa tanggung jawab terhadap diri sendiri. Pengabaian terhadap fitrah perkembangan yang ada pada dirinya, karena ketidaktahuan ataupun karena tidak ada arahan atau pendidikan yang memberikan pencerahan tentang apa dan bagaimana yang seharusnya dilakukan oleh orang yang sudah baligh.

Menanamkan kesadaran akan tanggung jawab serta perannya ditengah masyarakat juga bagian dari pendidikan yang berbasis fitrah. Yaitu tidak memaksakan sesuatu yang tidak sesuai dengan diri peserta didik sehingga tidak terjadi ketimpangan. Ketimpangan terjadi karena pendidikan yang tidak mengakar dan tidak mampu memandirikan individunya. Sehingga lahirlah generasi yang menengadah atau berpangku tangan pada orang lain dan mengabaikan kekayaan kearifan lokal dan kekuatan yang ada pada dirinya. Maka dibutuhkan pendidikan aqil baligh yang mampu mengaktualkan potensi fitrah untuk berkembang dengan baik dan dipandu oleh sistem hidup untuk 
menuju peran terbaiknya dengan akhlak dan adab yang mulia (Wahidah 2019).

Maka tujuan dari artikel ini adalah untuk mendiskusikan sisi yang belum mendapat perhatian yang luas bagaimana pendidikan akil baligh di sekolah dapat ditanamkan oleh para guru sehingga antara baligh dan aqil sejajar beriringan, tidak terjadi kesenjangan antara keduanya. Pendidikan aqil baligh hendaknya dapat dikembangkan disekolah sebagaimana kita melihat urgensinya yang mendesak sehingga nantinya ini akan dimasukkan khusus kedalam kurikulum sekolah baik secara nyata maupun tersembunyi. Sehingga kedepannya anak akan ada pembiasaan untuk mengenal tugas dan menyelesaikannya sebagai seorang manusia dewasa yang memiliki tanggung jawab atas dirinya.

\section{B. Landasan Teoritis}

Aqil baligh merupakan istilah dalam islam yang mengaitkan pubertas dengan kewajiban seseorang kepada sang Pencipta atas perubahan yang terjadi pada dirinya (Majelis Ulama Indonesia 2016:7). Aqil baligh usia SD dimulai sejak usia 10 tahun, tepatnya saat sekitar kelas 5 SD. Pada tahap ini anak membutuhkan tahap latih yang serius untuk segera mampu memikul syari'ah (mukallaf) dan mandiri atau dewas a secara mental, spiritual, emosional bahkan finansial ketika mereka mencapai usia 14-15 tahun (Santosa 2018:262). Sedangkan makna baligh yang biasa disandarkan dengan kata aqil berasal dari bahasa Arab yaitu 'aqala yang artinya berakal, mengetahui, dan memahami. Yaitu seseorang yang sehat, sempurna pikirannya, dapat membedakan baik dan buruk, benar dan salah, mengetahui dan memahami kewajiban, mengetahui aturan mana yang boleh dan mana yang dilarang dan memahami hal yang bermanfaat dan yang merusak, dalam kondisi sadar tanpa tekanan, bukan anak kecil, juga bukan lansia yang mengalami kelemahan mengingat, tidak sedang tidur, tidak sedang mabuk atau gila (Aynun 2018:42). 
Aqil adalah kondisi tercapainya kedewasaan psikologis, sosial, finansial, serta kemampuan memikul tanggung jawab syariah. Balighh artinya sampai, yaitu suatu kondisi tercapainya kedewasaan biologis dengan kematangan alat reproduksi sedangkan makna aqil juga dapat diartikan orang yang cukup umur (Santosa 2018:320). Di dalam ilmu fiqh, usia baligh ini dijadikan sebagai syarat untuk menjadi seorang mukallaf yaitu seseorang yang mengetahui atau mengerti hukum dan sudah sampai pada usia tertentu untuk dibebani hukum syariat (taklif). Isyarat mengenai istilah mukallaf dan taklif ini sebagaimana dijelaskan dalam Al-Qurán Surat al-Baqarah ayat 286. Dalam ayat tersebut, terdapat istilah yukallifu yang mengandung arti beban. Mukallaf yaitu seseorang yang mampu melakukakan tindakan hukum sehingga Allah memberikan tanggung jawab (beban) dengan kewajiban melaksanakan segala perintah dan menjauhi segala larangan Allah. Seseorang yang telah memenuhi kriteria akil balighh, telah memiliki kecakapan bertindak dan mencapai kedewasaan (Majelis Ulama Indonesia 2016:10).

Konsep pendidikan Islam, anak seharusnya sudah dewasa pada usia 15 tahun, dan sudah bisa bertanggung jawab (taklif) penuh dalam masalah ibadat, muamalat, munakahah dan jinayat (peradilan) selambat-lambatnya pada usia 17 tahun bagi wanita dan 18 tahun bagi Iaki-laki. Pada usia 21 tahun, anak lakilaki mestinya benar-benar sudah bisa lepas dari orangtua, tetapi harus membina kedekatan dan tetap menjaga ketaatan kepada orangtua (Adzim 2005:7). Aqil baligh merupakan istilah agama yang mengaitkan pubertas dengan kewajiban seseorang kepada sang Pencipta. Aqil baligh merupakan dua kata yang berbeda makna tetapi keduanya merupakan ciri yang digunakan untuk menunjukkan seseorang terikat kewajiban mentaati hukum atau dengan kata lain disebut mukallaf (Majelis Ulama Indonesia 2016:9).

Aqil maknanya matang secara akal dan baligh adalah matang secara fisik. Matang secara akal adalah dimana seseorang mampu mengambil peran dan tanggung jawab sebagai seorang manusia dewasa. Sedangkan matang secara fisik adalah saat semua fungsi tubuh sudah dapat difungsikan sebagaimana lazimnya orang dewasa, sehingga amatlah penting menyetarakan antara aqil dan baligh agar setiap tindakan dan fungsi tubuh seimbang dan dapat 
dipertanggungjawabkan. Masa anak-anak yang sesungguhnya berada pada rentang usia 0 sampai 10 tahun. Usia 0 sampai 6 tahun merupakan tahap penguatan dan perawatan konsepsi. Tahap ini merupakan masa keemasan fitrah keimanan. Anak-anak harus dihidupkan gairah cintanya pada kebenaran dan agama. Pada usia ini tidak boleh ada pembebanan apapun yang akan membuat trauma atau merusak fitrah.

Aqil baligh awal berada pada rentang usia 7 sampai 10 tahun. Pada usia ini semua konsepsi harus selesai menuju kepada penyadaran dan pertumbuhan semua potensi. Tahap ini adalah masa keemasan bagi fitrah belajar dan bernalar, anak sudah sangat kritis bernalar, kritisnya harus mengarah kepada kesadaran Allah-lah maha pengatur dan maha pelindung. Anak mulai menyadari keteraturan Ciptaan Allah di Alam semesta termasuk pada dirinya dan sosialnya. Inilah masa menuju tahap latih pre-aqilbaligh. Sholat mulai diperintahkan di usia 7 tahun sebagai penanda semua adab sudah diperintah dengan baik dalam aktivitas keseharian. Usia 10 tahun boleh di pukul (tidak melukai dan menghinakan). Boleh dipukul adalah peringatan, upayakan jangan sampai terjadi. Usia 10 tahun merupakan titik kritis mengenal Allah dan mengenal diri (bakat), serta mulai memiliki tanggung jawab sosial (Santosa 2018:261).

Usia 10 tahun potensi sudah siap dikokohkan dan diuji, maka ini adalah fase terberat karena anak-anak harus memasuki tahap latih pre-aqilbaligh sejak usia 10-14 tahun, yaitu tahap persiapan untuk mampu memikul beban syariah ketika baligh tiba, termasuk kemandirian dalam nafkah dan kemampuan zakat, jihad serta tanggung jawab sosial lainnya. Hal yang boleh dilakukan pada anak usia 10 tahun, diantaranya; 1) Boleh "dipukul" jika meninggalkan sholat, ini merupakan indikator mengenal Allah atau fitrah keimanan harus tuntas. 2) Kamar tidur harus dipisahkan antara pria dan wanita juga dengan ayah dan ibunya. Hal ini dilakukan agar fokus menjalani masa latih pre-aqilbaligh. 3) Bakat mulai dikenali dan didalami serta dikembangkan sebagai upaya mencapai peran peradaban (misi peradaban). Pada usia 10 sampai 14 adalah masa keemasan bagi fitrah bakat. 
Umumnya anak-anak telah baligh (haidh atau ihtilam) di usia 10 sampai 12 tahun, oleh karena itu di usia 10 sampai 14 tahun inilah tahapan saat anak menjadi sadar atau dewasa secara mental, spiritual, emosional bahkan finansial ketika mereka mencapai usia 14 sampai 15 tahun. Pada tahap ini anak harus disibukkan dengan kegiatan atau proyek produktif dan solutif sesuai fitrahnya. Agar tidak terlalu senjang antara baligh dan aqil sebagaimana sistem sosial dan pendidikan hari ini yang membocahkan berkepanjangan sejak usia 12 sampai 24 tahun. Berbagai kenakalan dan penyimpangan generasi muda adalah karena senjangan masa baligh (dewasa biologis) dan aqil (dewasa mental) diakibatkan sistem sosial dan sistem persekolahan yang melambatkan kedewasaan melalui pembocahan (infantization) yang panjang (Santosa 2018:262).

Rentang usia 7 sampai 10 tahun yang terpenting yaitu masa keemasan bagi fitrah bernalar, karena secara fitrah perkembangan pada saat usia 7 sampai 12 tahun, anak berada pada masa dimana otak kanan dan otak kiri sudah bertumbuh seimbang, ego sentris mulai bergeser ke sosiosentris sehingga mulai terbuka pada eksplorasi dunia di luar dirinya secara maksimal, indra sensomotoris diasumsikan sudah tumbuh sempurna pada fase sebelumnya, ada perintah sholat yang membutuhkan gairah belajar yang cukup setelah gairah keimanannya matang pada usia sebelumnya. Karenanya usia 7 adalah usia kritikal sebab ada perintah sholat di usia 7 tahun.

Teori hukum Islam menjelaskan mengenai rentang kehidupan manusia dibagi dua tahapan. Tahapan pertama ahliyah al-wujub (orang yang tidak memiliki tanggung jawab dan hanya memiliki hak); dan tahapan kedua adalah ahliyat al-ada' (orang yang bertanggung jawab bagi pelaksanaan taklif). Masing-masing tahapan terbagi lagi ke dalam dua siklus perkembangan. Tahapan pertama dibagi menjadi dua siklus perkembangan, yakni daur alijtinani (anak dalam kandungan) dan daur al-thufulah (anak usia dini). Sedangkan tahapan kedua terbagi menjadi daur al-tamyiz (usia sekolah, 7-14 tahun) dan daur bulugh 'aqil-an (usia pubertas, atau kedewasaan) (Fadlullah 2017). Seorang yang sudah memenuhi kriteria aqil baligh disebut mukallaf 
atau seseorang sudah mampu memikul beban hukum atau sanggup melaksanakan seluruh perintah Allah dan meninggalkan larangan-Nya.

Kemampuan seorang sanggup menerima beban hukum atau tanggung jawab diukur dengan kesempurnaan akal dan kesempurnaan akal ditetapkan dengan dua jalan yaitu; pertama dengan ciri-ciri khas kedewasaan seperti menstruasi bagi wanita atau ihtilam (keluar sperma) baik laki-laki maupun perempuan. Kedua dengan tercapainya umur tertentu. Apabila ciri-ciri kedewasaan tersebut tidak didapatkan pada seseorang karena ada gangguan jasmaniah maka ditetapka umur kedewasaan itu sejak 15 tahun baik laki-laki maupun perempuan (Yahya dan Rahman 1986:168). Sejak masa tanda kedewasaan ini seorang manusia sudah memikul seluruh tanggung jawab bagi dirinya terhadap berbagai perkataan maupun perbuatan yang mengandung pahala maupun dosa dalam persepektif agama Islam. Maka dalam pendidikan perlu diberikan pemahaman dan kesiapan untuk memikul tanggung jawab ketika sudah mencapai dewasa itu. Ia tidak boleh dilihat lagi sebagai seorang remaja tapi sudah dewasa dalam pandangan Islam.

\section{Metode}

Kajian ini fokus pada bagaimana penerapan konsep dan teori aqil baligh dalam pendidikan dengan menggunakan metode literatur review yang menggali berbagai informasi dari berbagai sumber tulisan baik buku, modul, artikel jurnal dan hasil penelitian lainnya (laporan penelitian/ skripsi, desertasi, atau tesis). Kemudian dianalisis untuk dikembangkan dalam diskusi akademik dalam pembahasan artikel ini.

\section{Hasil dan Pembahasan}

Pendidikan aqil baligh merupakan proses penanaman kesadaran tanggung jawab seorang manusia sejak di sekolah dasar. Untuk menerapkan pendidikan aqil baligh di sekolah dapat dilakukan dengan menempuh tiga langkah. Langkah pertama adalah membuat target pendidikan dengan jelas yaitu mendesain kurikulum yang tepat guna. Yaitu mensejajarkan kedewasaan bilogis, kedewasaan psikologis dan sosial serta finasial. Output ataupun hasil 
dari pembelajaran harus lebih jelas. Pendidikan merupakan kegiatan sentral dalam satu lembaga pendidikan manapun. Proses pendidikan nantinya akan menentukan output sumberdaya manusia yang akan dihasilkan yang kemudian mereka akan berperan di masyarakat dengan berbagai peran yang akan dilakukan. Islam memandang bahwa tujuan tertinggi dari pendidikan adalah memiliki kemampuan untuk mengaktulisasikan seluruh potensi kemanusian baik fisik maupun spiritualnya untuk menjalankan fungsi penghambaan kepada Allah swt dan fungsi kekhalifahannya dalam mengelola alam semesta bagi kemakmuran penduduk bumi.

Target yang ingin dicapai adalah mewujudkan tujuan pendidikan. Menurut Hasan Langgulung (1987) tujuan pendidikan harus selaras dengan tujuan hidup manusia itu sendiri yaitu menjadi manusia yang mampu bertanggung jawab untuk mengabdi kepada sang Pencipta sebagaima disebutkan dalam Alquran Surah Adz-Dzariat ayat 56 “ Dan tidak Aku (Allah) ciptakan jin dan manusia melainkan untuk menyebah-Ku". Secara fungsional tujuan dari penghambaan kepada Allah swt tersebut adalah menjadi khalifah yaitu memiliki pengetahuan dan keahlian untuk mengelola alam semesta ini guna meraih kesejahteraan dan kebahagian hidup dunia dan akhirat $(\mathrm{QS}$ : Albaqarah ayat 30). Sebagaimana disimpulkan oleh Hasan Langgulung (2004:56) bahwa tujuan akhir dari pendidikan dalam Islam adalah pembentukan pribadi khalifah bagi anak didik yang memiliki fitrah, roh, di samping badan, kemauan yang bebas, dan akal. Dengan kata lain tugas pendidikan adalah mengembangkan keempat-empat aspek ini pada manusia agar ia dapat menempati kedudukan sebagai khalifah.

Tujuan tersebut secara spesifik telah dicantumkan dalam tujuan pendidikan nasional di Indonesia yatu mengembangkan potensi peserta didik agar menjadi manusia yang beriman dan bertakwa kepada Tuhan Yang Maha Esa, berakhlak mulia, sehat, berilmu, cakap, kreatif, mandiri, dan menjadi warga negara yang demokratis serta bertanggung jawab (Pemerintah Indonesia 2003). Manusia sebagai makhluk yang tertinggi derajatnya diatara makhluk yang lain di alam semesta ini dibekali dengan berbagai potensi psikis (ruhaniah) dan fisik (jasmaniah) untuk menjalankan tanggung jawabnya. 
Untuk menciptakan masyarakat yang baik harus dimulai dari menciptakan manusia yang baik sebagai individu-individu yang akan melaksakan tugastugas kekhalifahannya di muka bumi. Penggalian potensi tersebut diaktualisasikan melalui proses pendidikan yang dijalankan secara terencana dan sistematis dalam sebuah kurikulum.

Rancangan kurikulum dimaksud harus merefleksikan hirarki alamiah manusia yang terdiri dari aspek ruhaniah dan jasmaniah. Sehingga kurikulum juga harus dikembangkan berdasarkan aspek ruhaniah dan fisiknya manusia. Artinya, kurikulum harus mampu menumbuhkembangkan manusia secara fisik (intelectual dan rational) dan juga secara spiritual (kesalehan, kesadaran, moral, kebijaksanaan). Pada aspek ruhaniah rancangan kurikulum berisi materi pengetahuan agama untuk menumbuhkan keyakinan secara langsung melalui refleksi dari Alquran yang menyediakan bimbingan moral serta tuntunan untuk menjalankan hubungan dalam masyarakat (Hashim 2004:112). Dengan materi pendidikan tersebut akan membentuk karakter yang baik lewat penanaman nilai yang baik atau adab dan menghilangkan kejahilan. Sementara aspek jasmaniah fokus pada pengembangan intelektual dan kemampuan rasional untuk memperkuat keimanan terhadap Tuhan melalui studi ciptaannya dan mengungkap hukum-hukum yang memampukan manusia untuk menciptakan sesuatu yang lebih baik. Aplikasi dari gagasan ini adalah kurikulum pendidikan disekolah tidak hanya transfer pengetahuan dari guru kepada peserta didik. Akan tetapi pendidikan juga sangat krusial dalam transfer adab dan karakter manusia yang bertanggung jawab tersebut.

Tujuan pendidikan sama dengan tujuan hidup, maka ia harus sejalan dengan misi penciptaan dirinya untuk menjadi rahmat bagi alam semesta (Santosa 2018). Sehingga setiap tahapan perkembangan peserta didik harus di isi dengan proses pembelajaran dan stimulasi yang sesuai sejak masa awal pertumbuhan hingga mencapai kedewasaan. Kesesuaian ini akan menjadikan seseorang mampu mengambil alih tanggung jawab (menanggung beban syariat/ mukalaf) baik dalam hal muamalah maupun syariah sesuai dengan karakteristik dan keunikan dirinya. Sehingga dirinya akan mampu berperan dan berkembang secara maksimal pada tiap tahapannya. Untuk mendapatkan 
kemampuan ini, sekolah sejak dari tingkat dasar hendaknya mengajarkan tentang peran dan tanggung jawab seseorang yang baliqh baik secara tersirat maupun tersurat. Agar tidak terjadi kesenjangan antara kematangan fisik (baliqh) dan kematangan akalnya (aqil). Hal ini dikarenakan umumnya, seorang anak mencapai tahapan baliqh pada usia 11-14 tahun, namun pada usia ini mereka belum dibebankan tanggung jawab dan masih dianggap anak anak yang belum mukalaf.

Aqil baligh dalam Islam bukan hanya ditandai dengan perubahan fisik, akan tetapi juga merupakan pertanda berpindahnya fase anak sebelum wajib syariah dan fase sesudahnya yaitu pemuda. Menurut Imam al-Ghazali, istilah Al-Aqil yaitu tingkat manusia yang telah berakal sempurna bahkan akal pikirannya telah berkembang secara maksimal sehingga telah menguasai ilmu dlaruri. Maka ketika seseorang mencapai aqil baligh ia tidak disebut lagi anak anak, tetapi setara dengan kedua orang tuanya dalam hal ibadah, zakat, jihad dan lainnya. Bahkan bagi anak laki laki, ulama fiqh sepakat orang tua tidak lagi wajib menafkahinya. Jika ada anak laki laki yang telah aqil baligh masih dinafkahi, maka itu sebenarnya bukan nafkah tetapi sedekah. Sehingga sistem pendidikan kita (khususnya Islam) harus mampu mempersiapkan (khususnya anak laki laki) agar mampu menjadi mukalaf (orang yang mampu memikul syariat) ketika tiba masa dia aqil baligh.

Kedua, proses pembelajaran lebih banyak yang berbasis proyek. Model Pembelajaran Berbasis Proyek/Kinerja merupakan model pembelajaran yang mengembangkan pemahaman konsep melalui investigasi masalah yang bermakna dan dapat menghasilkan suatu produk nyata (Alawiyah dan Sopandi 2016). Model pembelajaran ini dapat diupayakan untuk diterapkan sejak dini dan untuk semua mata pelajaran.

Memberikan kesempatan pada anak untuk belajar secara faktual akan segala sesuatu bukan hanya teori dan gambaran saja (Santosa 2018:197). Hal ini bisa melalui field trip (kunjungan lapangan), dengan menyusun aktifitas yang terstruktur dan menawarkan hasil. Contohnya dalam literatur Islam dijelaskan ketika anak sudah mencapai mumayyiz (7-14 tahun) sebagaimana dikutip oleh Fadlullah (2017) bahwa menurut Abu Hanifah, mumayyiz adalah 
anak yang mampu memahami jual beli (perdagangan) dan ia mengetahui bahwa menjual itu mencabut hak pemilikan atas barang yang dijual, sebaliknya membeli dapat menarik hak pemilikan lewat harga yang diberikan. Anak juga dapat mengetahui dan membedakan antara penipuan yang keji dengan "penipuan sedikit" seperti dalam promosi, yang dengan akad itu dimaksudkan akan tercapai keuntungan dan penambahan. Maka anak dengan bantuan supervisi orangtua dipandang kompeten (ahliyah) melakukan kegiatan bisnis dipasar, berjual beli secara praktis dan mendatangi pasar serta ikut terlibat dalam menentukan "harga". Kompetensi ini diketahui ketika anak dapat berbicara untuk membedakan dan menjelaskan berbagai hal, terutama terkait dengan perbedaan harga atau nilai suatu barang dan jasa. Maka dalam pendidikan yang bersifat pemagangan ini sangat berpengaruh dalam pembentukan karakter anak saat mencapai aqil baligh.

Magang di sini bukanlah magang seperti yang terjadi untuk orang dewasa yang melakukan praktek lapangan (PKL) siswa level SMA sederajat dan ke atasnya. Namun magang yang disesuaikan untuk anak sekolah khususnya usia SD dan SMP. Tujuan utamanya adalah untuk menitikberatkan pada mengolah keterampilan sosial dan keterampilan persoal, meningkatkan kemampuan memecah masalah sederhana, menumbuhkan kemandirian diri dan tim, meningkatkan disiplin juga kemampuan komunikasi (Sari 2017). Pengalaman praktik itu juga dapat berupa kegiatan berkomunikasi, kerjasama, mengambil keputusan dan memecahkan masalah. Pengalaman praktik tersebut juga mengembangkan kecerdasan untuk menemukan masalah, memecahkan masalah, dan menghargai prestasi pemecahan masalah (Dananjaya 2017:27).

Hal ini juga sejalan dengan pendapat Ibn Qayyim yang dikutip oleh Abdul Hafiz dan Hasni Noor (2016) yang menegaskan bahwa seorang anak hendaknya dijauhkan dari sifat malas, santai dan tidak mempunyai aktifitas positif, tetapi justru harus dibiasakan bekerja keras, sportif dan melakukan berbagai kesibukan. Karena pada dasarnya orang yang paling bahagia adalah mereka yang dapat bekerja dan melakukan aktifitas-aktifitas positif dan kontributif, sehingga membiasakan anak dengan keseriusan dan kesungguhan 
belajar dan beraktifitas akan berdampak positif pada pola hidupnya di kemudian hari.

Kegiatan yang bervariasi juga harus diberikan kepada anak saat ia mempelajari sesuatu, agar dia mampu memilih dan merasakan hal yang sesuai dan menyenangkan untuk dirinya. Hal ini berfungsi untuk mengarahkan anak pada identitas bakat dan minatnya. Mengenali minat anak juga akan mempermudah orang tua dan guru dalam memberi pengajaran dan mengarahkan perkembangannya (Sari 2017). Mengekspos anak pada beragam aktivitas akan lebih mudah baginya untuk menemukan kecendrungannya. Sehingga anak akan terhindar dari prilaku yang sia sia bagi dirinya. Kemampuan untuk mengisi waktu dengan kegiatan positif akan menghindarkan anak dari perilaku menyimpang. Model pembelajaran aktif hendaklah senantiasa diterapkan bagi anak didik agar dapat memberikan gambaran nyata akan suatu hal yang dipelajarinya.

Ketiga, guru dapat menciptakan komunitas belajar melalui model pembelajaran cooperative learning. Metode pembelajaran kooperatif learning terbukti dapat meningkatkan kemandirian belajar peserta didik. Kemandirian peserta didik juga dapat dipersiapkan dalam lingkungan sekolah dan masyarakat. Selain itu peserta didik dapat menyadari manfaat sikap mandiri dalam kegiatan di sekolah dan di tempat praktek kerja karena dapat meningkatkan rasa percaya diri, tanggung jawab, inisiatif dan terbuka akan perubahan (Yuliani dan Siliwangi 2019). Dengan adanya komunitas belajar akan memberikan anak pengalaman untuk dapat mengembangkan kemampuan sosialnya. Selain itu juga dapat melatihnya untuk bertanggung jawab ketika tugas diberikan pada masing masing anggota kelompok dan juga mengembangkan kemampuan afektif (empati, rasa sayang dan perasaan atau sikap lainnya). Pengalaman aktifitas siswa harus bersumber/relevan dengan realitas sosial, masalah-masalah yang berkaitan dengan profesi yang bervariasi seperti petani, pedagang, pengusaha, politikus berkaitan dengan masalah-masalah sosial seperti pelayanan umum, hak asasi manusia, gender, kemiskinan, keterbelakangan, dan lain-lain. 
Pembiasaan dan pengajaran merupakan salah satu sarana atau metode pendidikan anak. Jika anak selalu dibiasakan dan diajarkan untuk berbuat baik maka ia akan memiliki kecenderungan untuk berbuat baik sampai ia dewasa atau bahkan sampai tua. Hal itu terjadi karena nilai-nilai kebaikan telah meresap dalam dirinya dan telah menjadi pola pikir, sikap dan perilakunya. Untuk mengaplikasikan tugas-tugas pembelajaran lebih kreatif tersebut, maka setiap guru sangat dituntut untuk memiliki kompetensi dalam proses pembelajaran, sehingga tercapai tujuan atau sasaran yang diharapkan dalam proses pembelajaran. Kompetensi merupakan salah satu kualifikasi guru yang terpenting. Sebab guru harus dapat memenuhi kompetensi yang diharapkan oleh masyarakat dan anak didik dalam melaksanakan pendidikan dan pembelajaran (Manizar 2018). Peran guru sebagai fasilitator menjadi penting untuk tetap menjadi sumber inspirasi keteladanan bagi peserta didik.

\section{E. Kesimpulan}

Banyaknya kasus kenakalan remaja yang terjadi karena pendidikan yang tidak mengakar dan tidak mampu memandirikan individunya. Konsekwensinya melahirkan generasi yang menengadah atau berpangku tangan pada orang lain dan mengabaikan kekayaan kearifan lokal dan kekuatan yang ada pada dirinya. Pendidikan aqil baligh menjadi penting untuk diterapkan di sekolah sehingga mampu mengaktualkan potensi fitrah generasi bangsa untuk berkembang dengan baik dan dipandu oleh sistem hidup untuk menuju peran terbaiknya dengan akhlak dan adab yang mulia sesuai dengan tujuan pendidikan nasional. Pendidikan aqil baligh di sekolah dapat dilakukan dengan menempuh tiga langkah. Langkah pertama adalah membuat target pendidikan dengan jelas yaitu mendesain kurikulum yang tepat guna yang sejalan dengan pendidikan nasional. Sehingga akan mensejajarkan kedewasaan bilogis, kedewasaan psikologis dan sosial serta finasial. Kedua, menerapkan proses pembelajaran yang berbasis proyek yaitu model pembelajaran yang mengembangkan pemahaman konsep melalui investigasi masalah yang bermakna dan dapat menghasilkan suatu produk nyata seperti magang. Ketiga, pembelajaran dengan menciptakan komunitas belajar melalui 
model pembelajaran cooperative learning. Metode pembelajaran kooperatif learning terbukti dapat meningkatkan kemandirian belajar peserta didik.

\section{DAFTAR PUSTAKA}

Adzim, Mohammad Faudzil. 2005. Positive Parenting, AsyikJadi Orang Tua Bagi Para Ayah. Yogyakarta: Pro-U Media.

Alawiyah, I., dan W. Sopandi. 2016. "Pembelajaran Berbasis Proyek Untuk Meningkatkan Sikap Ilmiah Siswa Sekolah Dasar Pada Materi Peristiwa Alam." Jurnal Penelitian Pendidikan 16(2):167-76.

Aynun, Nur. 2018. Mendidik Anak Pra-Aqil Baligh. Jakarta: PT. Elek Media Komputindo.

Bella, Sheila Melinda, dan Farida Istianah. 2017. "Pendidikan Seksualitas Sejak Dini sebagai Upaya Menghindarkan Anak-Anak Usia Sekolah Dasar dari Penyimpangan Seksualitas." JPGSD: Jurnal Penelitian Pendidikan Guru Sekolah Dasar 05(03):1-12.

Dananjaya, Utomo. 2017. Media Pembelajaran Aktif. Cet. IV. diedit oleh F. Manshur dan M. A. Elwa. Bandung: Nuansa.

Fadlullah. 2017. "Pendidikan Anak Usia Dini dalam Perspektif Islam.” Ta'dib: Jurnal Pendidikan Islam 6(2):65-74.

Hadisuprapto, Paulus. 2004. "Studi Tentang Makna Penyimpangan Perilaku Di Kalangan Remaja." Jurnal Kriminologi Indonesia 3(III):9-18.

Hafiz, Abdul, dan Hasni Noor. 2016. "Pendidikan Anak Dalam Perspektif Alquran." Muallimuna: Jurnal Madrasah Ibtidaiyah 1(2):112-27.

Hashim, Rosnani. 2004. Educational Dualism in Malaysia Implications for Theory and Practice. Second. Selangor-Malaysia: The Other Press.

Langgulung, Hasan. 1987. Asas-Asas Pendidikan Islam. Cetakan ke. Jakarta: Pustaka Al-Husna.

Langgulung, Hasan. 2004. Manusia \& Pendidikan Suatu Analisa Psikologis, Filsafat dan Pendidikan. Jakarta: Pustaka Al-Husna Baru.

Majelis Ulama Indonesia. 2016. Haid dan Kesehatan Menurut Ajaran Islam. Jakarta: Sekolah Pascasarjana Universitas Nasional.

Manizar, Elly. 2018. “Optimalisasi Pendidikan Agama Islam di Sekolah." Tadrib: Jurnal Pendidikan Agama Islam 3(2):251-77. 
Mukhlas, Moh. 2008. "Aktualisasi Konsep Pendidikan Akhlak Al-Ghazali Dalam Pembinaan Remaja.” At-Ta'dib: Journal of Pesantren Education 3(1):1940.

Pemerintah Indonesia. 2003. UU No. 20 Tahun 2003 Tentang Sistem Pendidikan Nasional. Jakarta.

Putri, Densi Sah. 2018. "Faktor-Faktor yang Mempengaruhi Prilaku Menyimpang Remaja (Studi Kasus Pada Remaja Kecanduan Komix Obat Batuk di Desa Palak Bengkerung Kabupaten Bengkulu Selatan), Skripsi S1." IAIN Bengkulu.

Rochaniningsih, Nunung Sri. 2014. "Dampak Pergeseran Peran dan Fungsi Keluarga pada Prilaku Menyimpang Remaja." Jurnal Pembangunan Pendiidikan : Fondasi dan Aplikasi 2(1):59-71.

Santosa, Harry. 2018. Fitrah Based Education. Bekasi: Yayasan Cahaya Mutiara Timur.

Sari, Dewi Citra. 2017. Magang Yuk! Merancang Aktivitas Magang ala ABHome. I. diedit oleh S. Patria. Depok: Tosca Jaya Indonesia.

Sholichah, Aas Siti. 2020. "Pendidikan Karakter Anak Prabaligh Berbasis AlQur'an." Al Amin: Jurnal Kajian Ilmu dan Budaya Islam 3(1):151-74.

Sumara, Dadan, Sahadi Humaedi, dan Meilanny Budiarti Santoso. 2017. "Kenakalan Remaja dan Penanganannya." Prosiding Penelitian dan Pengabdian kepada Masyarakat 4(2):346-53.

Susanti, Iis. 2015. "Perilaku Menyimpang Dikalangan Remaja Pada Masyarakat Karangmojo Plandaan Jombang.” Paradigma: Jurnal Online Mahasiswa S1 Sosiologi UNESA 3(2):1-6.

Unayah, Nunung, dan Muslim Sabarisman. 2015. "Fenomena Kenakalan Remaja dan Kriminalitas." Sosio Informa 1(02):121-40.

Wahidah. 2019. “Urgensi Pendidikan Berbasis Fitrah.” Al-Ikhtibar: Jurnal Ilmu Pendidikan 6(1):580-89.

Yahya, Muktar, dan Fatchur Rahman. 1986. Dasar-Dasar Pembinaan Fiqh Islami. Bandung: Alma'arif.

Yuliani, Wiwin, dan Ikip Siliwangi. 2019. "Pengaruh Metode Kooperatif Learning Tipe Jigsaw Terhadap Kemandirian Belajar Peserta Didik Kelas VI SDN Tunas Bakti Subang Tahun Pelajaran 2018 / 2019." QUANTA 3(2):39-43. 